\title{
Regeringens beskæftigelsespolitik - en økonomisk-politisk kommentar til Flere i Arbejde
}

\author{
Henning Hansen, Jens Lind \& Iver Hornemann Meller
}

I artiklen vurderes og kommenteres Flere i Arbejde set i en sammenhæng med de øvrige elementer i regeringens beskæftigelsespolitik, herunder strukturreformen, og artiklen konkluderer, at reformen indeholder en række traditionelle elementer, som blot er fortsættelsen af tidligere regeringers reguleringer, men på visse punkter har regeringen også indført en politik med stærke liberalistiske overtoner, som kan få vidtrækkende konsekvenser for reguleringen af arbejdsmarkedet i Danmark.

\section{Indledning}

$\mathrm{R}$ egeringens reform Flere $i$ Arbejde fra 2002 (Beskæftigelsesministeriet 2002) sigter som navnet antyder, primært mod at bringe flere i arbejde. Om dette så også er lykkedes, vil vi - efter en kort præsentation af nogle af hovedlinierne i reformen - kort beskæftige os med i starten af artiklen. Men ellers vil vi diskutere Flere i Arbejde i et lidt bredere perspektiv, hvor vi vil inddrage regeringens øvrige beskæftigelsespolitiske indsatser i perioden siden 2001. Vort sigte med artiklen er således ikke at gennemgå og evaluere konsekvenserne af samtlige elementer af Flere i Arbejde, men derimod at sætte hovedlinierne i reformen ind i en bredere sammenhæng og i den forbindelse søge at belyse, om reformen er udtryk for en større ændring af den tidligere førte politik, eller den bare er en videreførelse af en allerede etableret linie i de senere års socialog arbejdsmarkedspolitik.

Det overordnede tema er således kontinuitet eller forandring i beskæftigelsespolitikken. Allerede med valget af dette begreb kan der spores en forandring i forhold til tiden før 2001. Med regeringens omdøbning af Arbejdsministeriet ved sin tiltrædelse var der måske allerede signaleret den sammenlægning af opgaver, som blev nærmere fastlagt i Flere i Arbejde. En ny regerings rokade af nogle opgaver mellem nogle ministerier og nedlæggelse og oprettelse af ministerier er ikke noget særsyn og behøver ikke at indvarsle markante ændringer i politikken. Det er heller ikke nødvendigvis tilfældet her, men som det vil fremgå af artiklen, er det primært i de strukturelle forandringer af politikkens forvaltning og deraf følgende anden adfærd hos aktørerne, at vi finder de mest markante tendenser til brud med den tidligere social- og arbejdsmarkedspolitik. Kontinuiteten ligger mest i politikkens indhold.

Omlægningen af strukturen i den offentlige sektor, 'Kommunalreformen', indeholder således også en række elementer, der er af betydning for beskæftigelsespolitikken. Uden at vi skal gå ind på denne diskussion i detaljer, må det siges at være en markant ændring, at regeringen vil overføre en stor 
del af arbejdsmarkedspolitikken til kommunerne. Dette vil få betydelige konsekvenser for forvaltningen af hele politikområdet, herunder indflydelsen fra arbejdsmarkedets parter, jævnfør øvrige bidrag i dette nummer af Arbejdsliv.

Flere i Arbejde har snævert set ikke så meget at gøre med den øvrige politiske og aftalemæssige regulering af arbejdsmarkedet, men da vores udgangspunkt for artiklen er sammenhængen i regerings beskæftigelsespolitik, vil vi også inddrage hovedtrækkene i den generelle økonomiske politik og det kollektive aftalesystem og parterne på arbejdsmarkedet. Et regeringsskifte medfører ikke nødvendigvis forandringer i disse reguleringer. Den overordnede politisk-økonomiske strategi kan skifte eller videreføres nogenlunde uændret, men blandt de nogenlunde stabile sammenhænge i Danmark er vægtningen af det kollektive aftalesystem: Der er bred konsensus i Danmark om, at relationerne på arbejdsmarkedet bedst reguleres gennem den fri aftaleindgåelse og ikke gennem lovgivning. Det gælder i hvert fald de væsentligste relationer som løn og arbejdstid, medens andre reguleringer vedr. betingelserne for arbejdskraftens anvendelse både kan være aftalemæssigt eller lovgivningsmæssigt fastlagte.

Forhold vedrørende arbejdskraftens produktion og reproduktion, uddannelse samt sociale rettigheder og ydelser, er oftest lovgivningsmæssigt reguleret. Uddannelsespolitikken, socialpolitikken, aktiv arbejdsmarkedspolitik og aktiveringspolitikken er typiske områder for lovgivningsmæssig regulering. Men demarkationslinien mellem aftaleindgåelse og lovgivning er alligevel ofte pragmatisk og bestemt af aktuelle muligheder og hensyn. Således er arbejdstiden igennem de senere år blevet stærkt påvirket af EU-reguleringer med efterfølgende dansk lovgivning, ligesom pensioner og på det seneste barselsorlov er blevet aftalemæssigt fastlagt.
Et særtræk ved den danske model er måske netop en pragmatisk forholden sig til dogmerne om, hvordan arbejdsmarkedet reguleres. For at kunne vurdere den sammenhæng, som programmet Flere i Arbejde indgår i, skal vi medtænke den generelle økonomiske politik, den aftalemæssige regulering af arbejdslivet og de øvrige lovgivningsmæssige initiativer, som regeringen er kommet med på beskæftigelsesområdet. I denne forbindelse kan man vel på forhånd antage, at Fogh-regeringens reguleringer bærer præg af en lidt stærkere liberalistisk prægning end den tidligere socialdemokratiske regering. Et markant træk ved de borgerlige partiers ideologi er netop, at de fremstiller sig selv som frihedens forkæmpere. Først og fremmest skal markedskræfterne slippes løs. Samfundet skal (helst) have en fri prisdannelse på alle markeder, og oveni skal den enkelte samfundsborger have et 'frit valg' til at bestemme, hvordan livet skal leves. Der skal ikke være for mange restriktioner. Sagt på en anden måde skal statens indflydelse begrænses, mens markedet og det civile samfund skal styrkes.

\section{Hovedtrækkene i Flere i Arbejde}

I sommeren 2002 vedtog et flertal af folketingets partier regeringens arbejdsmarkedsreform Flere i Arbejde. Målet med reformen var at øge beskæftigelsen med 87.000 personer inden år 2010. Det var regeringens tanke, at der skulle komme 20.000 flere i beskæftigelse ved at nedbringe ledigheden og resten ved at øge arbejdsstyrken.

Regeringens begrundelse for reformen var, at for mange blev aktiveret i nyttesløse projekter og uddannelsesordninger uden at opnå ordinær beskæftigelse. Derfor skulle individet sættes i centrum, og indsatsen tage udgangspunkt i den enkeltes behov og ikke i, hvorvidt den enkelte er forsikret eller ej. Et væsentligt element i reformen var derfor at ligestille indsatsen for kontant- 
hjælpsmodtagere og dagpengemodtagere. Reformens grundlæggende idé var, at det handler om, at den enkelte (ledige) skal rustes og motiveres til at søge og opnå beskæftigelse på det ordinære arbejdsmarked. Det skal kunne betale sig at arbejde. Det skal samtidig sikres, at alle ledige står reelt til rådighed for arbejdsmarkedet. Og endelig handler det om den kortest mulige vej til beskæftigelse.

De tidligere begreber som individuel handleplan, jobtræning etc. blev udskiftet med jobplan, ansættelse med løntilskud mv. Mere konkret handlede reformen om:

- Enstrenget arbejdsmarkedssystem.

- En liberalisering af AF's drift - andre aktører skal inddrages i beskæftigelsesindsatsen.

- En forenkling af redskabsviften - fra 32 ordninger til 3, nemlig vejledning/opkvalificering, virksomhedspraktik og løntilskud.

- Ændring i rådighedsregler og sanktioner det skal kunne betale sig at arbejde.

De organisatoriske ændringer handlede primært om, at kommunerne skal servicere ledige kontanthjælpsmodtagere efter samme principper som AF. Det betyder, at ledige uanset forsørgelsesgrundlag får samme rettigheder og pligter. Der er i den forbindelse lagt op til at styrke samarbejdet mellem kommunerne og AF. Det skal ses i sammenhæng med forslaget om den strukturreform, som drøftes i øjeblikket.

Reformen indebar desuden, at andre aktører skulle inddrages i beskæftigelsesindsatsen, bl.a. ved at en række af AF's ydelser skulle udliciteres. I første omgang blev de 14 AF-regioners kontaktforløb for udvalgte ledige udbudt i licitation. Derefter skulle flere elementer af indsatsen for de ledige efterhånden udliciteres. Et vigtigt element $i$ denne udlicitering var, at øvrige aktører skulle resultataflønnes.
Den tidligere store 'redskabsvifte' med de 32 ordninger og redskaber blev erstattet med tre tilbud, som nu både gælder for dagpenge- og kontanthjælpsmodtagere. De tre tilbud er:
a) vejledning/opkvalificering
b) virksomhedspraktik og
c) ansættelse med løntilskud

De tre tilbud er i virkeligheden ikke nye, men er en samling af de hidtidige redskaber i tre overordnede redskabsgrupper. Hensigten var at pointere nødvendigheden af at placere de ledige i 'rigtigt' arbejde frem for $i$ diverse aktiverings- og uddannelsesprojekter. Samtidig blev uddannelse og kompetencegivende opkvalificering kraftigt nedtonet.

Der skal også nævnes en anden væsentlig ændring. Tidligere måtte ledige i eksempelvis jobtræning kun udføre arbejde, der ellers ikke ville blive udført, og der var begrænsninger for typen af arbejde, der måtte udføres. Med reformen er disse begrænsninger fjernet, således at ledige ansat med løntilskud i dag må lave al slags arbejde. Argumentet for at fjerne disse tidligere restriktioner er, at det vil forbedre lediges muligheder for at opnå fodfæste på arbejdsmarkedet. Det er heller ikke længere et krav, at medarbejderrepræsentanter skal give tilsagn i forbindelse med ansættelse af ledige med løntilskud. Det er alene et krav, at tillidsrepræsentanten er blevet informeret og har talt med ledelsen.

Rådighedsforpligtelsen blev også strammet med reformen. Personer, der takker nej til et tilbud, selv siger op eller stopper i en uddannelse, får tre ugers karantæne. I den periode får dagpengemodtageren ingen dagpenge, og kontanthjælpsmodtageren får ydelsen reduceret med $1 / 3$. Afslår en person anden gang inden for en 12 måneders periode, stilles der krav om 300 timers ordinært arbejde inden for 10 uger. Indtil kravet er 
Tabel 1: Udviklingen i beskaeftigelsen 1998-2004 (3. kvartal - saesonkorrigeret). ATP-statistik.

\begin{tabular}{|l|c|r|r|c|}
\hline & 1998 & 2001 & 2004 & $\begin{array}{c}\text { Fuldtids- } \\
\text { beskæftigede } \\
\text { i tusinder }\end{array}$ \\
\hline I alt & 100 & 102,1 & 100,7 & 2.188 \\
Den private sektor & 100 & 102,9 & 100,5 & 1.343 \\
Den statslige sektor & 100 & 93,8 & 90,2 & 154 \\
Den amtslige sektor & 100 & 103,6 & 104,7 & 177 \\
Den kommunale sektor & 100 & 101,8 & 104,0 & 431 \\
Offentlige selskaber & 100 & 102,0 & 98,4 & 79 \\
\hline
\end{tabular}

Kilde: Danmarks Statistik: Statistikbanken

opfyldt modtager dagpengemodtageren ingen dagpenge, og kontanthjælpsmodtageren får sin ydelse reduceret med $1 / 3$.

For at sikre sig, at der er et økonomisk incitament for alle grupper til at arbejde, justeres kontanthjælpen til ægtepar. Det betyder, at kontanthjælpen sænkes hhv. 80\% og 60\% for begge efter seks måneder. For dimittender er der ikke længere mulighed for at optjene ret til fulde dagpenge ved at have fuldtidsarbejde $\mathrm{i}$ tre måneder inden for en given periode. For udeboende kontanthjælpsmodtagere under 25 år uden børn, reduceres kontanthjælpen efter seks måneder, således at ydelsen svarer til niveauet for statens uddannelsesstøtte (SU). Hensigten med nedjusteringen er at give unge et incitament, så de ikke af økonomiske årsager holder sig fra at tage uddannelse.

Endelig er kravene til transporttid skærpet. Ledige skal i dag sige ja til job, selvom det medfører en samlet daglig transporttid på fire timer. For mellem- og højtuddannede stilles der krav om yderligere øget mobilitet ud over de fire timer.

\section{Flere $\mathbf{i}$ arbejde?}

Er der så kommet flere i arbejde efter 2001? Og vil der komme 87.000 flere i arbejde inden 2010, sådan som målsætningen er i re- geringens udspil Flere i Arbejde? VK-regeringen forventede helt tydeligt at kunne køre videre på den beskæftigelsesfremgang, som havde fundet sted siden midten af 1990'erne, men et blik på beskæftigelsesstatistikken er nok til at konstatere, at det ikke ser lovende ud. Arbejdsløsheden har været stigende og beskæftigelsen faldende i de seneste år. Regeringens beskæftigelsespolitik har ikke kunnet dæmme op for den økonomiske afmatning og faldende beskæftigelse.

Fra 2001 til 2004 er den samlede beskæftigelse faldet med 1,4\%. Og det er interessant, at det er i den private sektor, faldet i beskæftigelse siden 2001 har været størst. Beskæftigelsesnedgangen har været ligeligt fordelt over næsten alle brancher i den private sektor. Derimod er beskæftigelsen steget i kommunerne og amterne. Beskæftigelsesmæssigt har det altså ikke været nogen succes med en liberal VK-regering.

Når vi ser på ledighedstallene, så er det også gået den forkerte vej siden regeringsskiftet. Den registrerede ledighed er steget med ca. 17\%, og den 'samlede' ledighed (inkl. personer i støttet beskæftigelse og uddannelse samt aktivering) er steget med næsten 13\%. I dag er den registrerede ledighedsprocent $6,2 \%$, og den 'samlede' ledighedsprocent er 10,2\%. Det er også interessant, at ledigheden er steget for næsten alle grupper. 
Tabel 2: Udviklingen i ledighed og personer uden ordinaer beskaeftigelse. 2000-2003. (\% af arbejdsstyrken).

\begin{tabular}{|l|c|c|c|c|}
\hline & 2000 & 2001 & 2002 & 2003 \\
\hline Registreret ledighed & $5,4 \%$ & $5,2 \%$ & $5,0 \%$ & $6,2 \%$ \\
$\begin{array}{l}\text { Støttet beskæftigelse } \\
\text { Uddannelses- } \\
\text { foranstaltninger }\end{array}$ & $1,2 \%$ & $1,4 \%$ & $1,8 \%$ & $2,0 \%$ \\
$\begin{array}{l}\text { Aktivering mv. } \\
\begin{array}{l}\text { I alt uden ordinær } \\
\text { beskæftigelse }\end{array}\end{array}$ & $1,6 \%$ & $1,6 \%$ & $1,6 \%$ & $1,3 \%$ \\
$\begin{array}{l}\text { Antal uden ordinær } \\
\text { beskæftigelse }\end{array}$ & $9,9 \%$ & $0,8 \%$ & $0,8 \%$ & $0,7 \%$ \\
\hline
\end{tabular}

Kilde: CASA \& Socialpolitisk Forening 2004.

Men hvad har regeringen gjort ved beskæftigelsen? Den har bl.a. ændret aktiveringsindsatsen, så uddannelse spiller en mindre rolle, mens løntilskud i den private sektor spiller en større rolle (se en anden artikel i dette temanummer om uddannelsesindsatsen). Desuden har den indført motiverende foranstaltninger, som bl.a. omfatter loft over kontanthjælpen, så kontanthjælpsmodtagere med store boligudgifter får nedsat hjælp. Desuden er der indført varighedsgrænser, som betyder lavere kontanthjælp for visse personer efter 6 måneder på kontanthjælp. I et svar fra Beskæftigelsesministeren til Villy Søvndal (SF), som er refereret i Politiken den 13. og 14. juli 2004, havde ca. 50.000 personer mærket disse stramninger af kontanthjælpsreglerne. Disse motiverende foranstaltninger, som især vil ramme indvandrergruppen, har nærmest karakter af at ville 'sulte' nogle kontanthjælpsmodtagere til selvforsørgelse.

Nye modtagere af introduktionsydelse og starthjælp får en sats, som kun er ca. to tredjedele af kontanthjælpen. Der er imidlertid betydelig forskel på disse to grupper, idet modtagere af starthjælp i de fleste tilfælde har en betydelig større tilknytning til Danmark end modtagere af introduktionsydelse. Men tabel 3 viser, at modtagere af de lavere ydelser ikke klarer sig bedre end modtagere af 'høje' ydelser.

Man kan opgøre beskæftigelses-/uddannelseseffekten i sammenligning med andre sociale ydelser. I tabel 3 vises hvor stor en procentdel af de personer, som i 3. kvartal 2002 og i 1. kvartal 2003 modtog en ydelse, der i midten af 2004 var blevet selvforsørgende eller var i gang med en ordinær uddannelse.

Tabel 3 viser, at den bedste effekt har 'nye på kontanthjælp', efterfulgt af 'nye på starthjælp' og 'nye i aktivering'. I bunden finder vi de 'gamle' på kontanthjælp og aktivering, og på linje med dem er nye på introduktionsydelse.

Starthjælpen og den lavere sats for introduktionsydelsen, som blev indført i juli 2002 har imidlertid ikke haft nogen større effekt på beskæftigelsen. Det har CASA tidligere dokumenteret $i$ en rapport om integrationsydelse og starthjælp (Hansen \& Hansen 2004) og i Social Årsrapport 2003 og 2004, hvor man har opgjort beskæftigelsesprocenten efterfølgende. Det viser sig, at ca. 30\% af de nye modtagere af introduktionsydelse efterfølgende kommer i beskæftigelse eller i uddannelse både før og efter 1 . juli 2002. Arbejdsdirektoratet har opgjort tallene på en lidt anden måde og har fun- 
Tabel 3: Procentdel selvforsørgende eller i uddannelse i midten af 2004 - opdelt efter ydelsesart.

\begin{tabular}{|l|c|c|}
\hline & Fik ydelse i 3. kvartal 2002 & Fik ydelse i 1. kvartal 2003 \\
\hline Nye på introduktionsydelse & $30 \%$ & $30 \%$ \\
Nye på starthjælp & $47 \%$ & $50 \%$ \\
Nye på kontanthjælp* & $59 \%$ & $54 \%$ \\
Nye i aktivering* & $49 \%$ & $48 \%$ \\
'Gamle' på kontanthjælp** & $28 \%$ & $28 \%$ \\
'Gamle' i aktivering ** & $28 \%$ & $28 \%$ \\
\hline
\end{tabular}

* Har ikke modtaget kontanthjælp eller været i aktivering efter 2000.

** Har også modtaget kontanthjælp eller været i aktivering før det pågældende kvartal.Kilde: Beskæftigelsesministeriets DREAM-database.

Kilde: Beskæftigelsesministeriets DREAM-database.

det, at kun ca. fem procentpoint flere er kommet i beskæftigelse/uddannelse efter indførelsen af de laverer satser. Men uanset hvilken metode man benytter, så er konklusionen, at lavere ydelse ikke har nogen særlig effekt på beskæftigelsen eller selvforsørgelsen - højst fem procentpoint. Spørgsmålet er endda, om man kan tillade sig at konkludere, at der er tale om beskæftigelse, når en person ikke længere modtager en offentlig ydelse. I visse tilfælde mister en person nemlig sin kontanthjælp, hvis ægtefællen får beskæftigelse. I DREAM-databasen bliver dette tolket som beskæftigelse. Hvor mange det drejer sig om, ved vi ikke.

Man kan tale om, at VK-regeringen har drevet de økonomiske incitamenter så langt, at det har mening at tale om et nyt princip, hvor man vil 'sulte' folk, som i forvejen har svært ved at klare sig på arbejdsmarkedet. I værste fald risikerer man at gøre en gruppe kriminelle, fordi nogle af de ramte personer sandsynligvis vil vælge et liv på kanten af samfundet med sort arbejde og momsfri handel.

Det skal også ses på baggrund af, at øget beskæftigelse er afhængig af meget andet end den førte beskæftigelsespolitik. Beskæftigelsespolitikken kan justere på kvantiteten og kvaliteten af arbejdskraftudbuddet, men den økonomiske vækst er afgørende for ændringer i beskæftigelsen, og den til enhver tid siddende regering har kun begrænset indflydelse på beskæftigelsesudviklingen.

\section{Beskæeftigelses- og arbejdsmarkedspolitikken} Den generelle økonomiske politik

Paradigmeskiftet fra en keynesiansk til en monetaristisk økonomisk politik fandt i Danmark gradvist sted i løbet af 1980'erne og 1990'erne. I løbet af denne periode blev det i stigende grad accepteret, at den statslige finanspolitik ikke længere skulle bruges til at stimulere den effektive efterspørgsel efter varer og tjenester (nogen taler dog om den såkaldte 'kickstart' i 1993-94, hvor underskuddet på de offentlige finanser var over 3\%). I stedet har først rentesænkningerne og senere skattesænkningen i 2004 skullet fremme efterspørgslen. Schlüter-regeringens tiltrædelse i 1982 markerede det første skridt i dette skifte fra et inflationært til et ikke-inflationært vækstregime. Tiltrædelsen til det indre marked og den såkaldte Fælleserklæring fra 1987 (Regeringen 1987) og Maastricht-traktaten i 1992 er nogle andre vigtige milepæle, og endelig har fagbevægelsens reelle accept i løbet af 1990'erne medført, at det ikke-inflationære vækstregime har bred politisk og institutionel opbakning i Danmark.

Konvergenskravene og senere stabilitet- 
spagten er således den væsentligste referenceramme for den økonomiske politik for både den foregående og den nuværende regering. Frem til 2001 viste denne politik sig vellykket, og Danmark blev af mange anset for en model for den europæiske strategi. Danmark var beviset på, at det kunne lade sig gøre at realisere en stabil økonomisk og beskæftigelsesmæssig vækst, der medførte, at arbejdsløsheden fra 1994 til 2001 faldt fra 12 til fem procent, uden større statslige budgetunderskud. I samme periode var inflationen lavere end lønstigningerne, og størstedelen af befolkningen havde en reallønsfremgang.

Siden 2001 har inflationen også været mindre end lønstigningerne, og efter et fald i den økonomiske vækst formodes den igen at ligge over to procent i 2004 og de næst følgende år. Til trods herfor har beskæftigelsen som nævnt været faldende og arbejdsløsheden stigende siden 2001. Alligevel er regeringen fortsat optimistisk, og den regner med, at beskæftigelsen vil stige fra nu af (Finansministeriet 2004).

Anlægges et lidt mindre optimistisk syn, kan det konstateres, at det ikke-inflationære regime frem til 2001 havde en positiv effekt på dansk økonomi og beskæftigelse først og fremmest gennem den efterspørgselsstimulering, der fandt sted som følge af rentefaldet - medens det efter 2001 har vist sig at være knapt så vellykket, hvilket i høj grad også kan ses i andre lande i Europa, hvor bl.a. Tyskland og Frankrig har set sig nødsaget til at overskride stabilitetspagtens aftaler om underskuddet på de offentlige budgetter (DØR 2004).

Rentefaldet er fortsat efter regeringsskiftet i 2001, og regeringen har søgt at stimulere efterspørgslen yderligere gennem skattereduktioner i 2004, som formodentlig har været medvirkende til et mindre fald $\mathrm{i}$ arbejdsløsheden siden 2003, men altså indtil videre uden de forventede beskæftigelsesmæssige effekter.

\section{Arbejdsmarkedspolitikken}

Der er naturligvis mange andre faktorer end rentefaldet, der spillede ind på den positive beskæftigelsesudvikling fra 1994 til 2001. En af disse hævdes som regel at være beskæftigelsespolitikken, som netop fik fornyet aktualitet efterhånden som statens finanspolitiske råderum blev begrænset. Gennem større fleksibilitet på arbejdsmarkedet kan det sikres, at arbejdskraften allokeres mere effektivt, hvorved konkurrenceevne, økonomisk vækst og dermed beskæftigelsen fremmes, og også her på det beskæftigelsespolitiske område blev Danmark af mange betragtet som et foregangsland med en høj fleksibilitet på arbejdsmarkedet kombineret med relativt høje sociale ydelser og en aktiv arbejdsmarkedspolitik (Auer 2000; Ganssmann 2000). 'Flexicurity' blev i løbet af 1990'erne samlebegrebet for en strategi (Transfer 2004), der indeholdt en hensyntagen til både lønmodtageres og arbejdsgiveres interesser - arbejdsgiverne fik fleksibilitet og lønmodtagerne social tryghed.

De socialdemokratiske regeringer i perioden 1993-2001 startede ud med en større lovpakke, der på arbejdsmarkedsområdet indeholdt en forøget vægt på aktivering af de arbejdsløse, en udvidelse af orlovsordningerne og en begrænsning $i$ adgangen til arbejdsløshedsunderstøttelse, bl.a. ved at afskaffe optjeningsretten under støttet beskæftigelse (Lind 1995). Frem til 2001 blev aktiveringsbestræbelserne yderlige styrket gennem en række tiltag, såsom fremrykning af aktiveringskravene (specielt for unge) og etablering af særlige ordninger, såsom servicejobs. Videre blev orlovsordningerne kraftigt reduceret, overgangsydelsen afskaffet, efterlønsordningen forringet og adgangen til arbejdsløshedsdagpenge yderligere begrænset gennem bl.a. en reduktion af støtteperioden fra ni til fire år, strengere rådighedskrav og en længere periode for optjeningsret. Endelig blev dag- 
pengenes dækningsgrad i forhold til lønnen reduceret (Lind \& Møller 2004).

Sammenfattende om denne periode kan det således påstås, at arbejdsmarkedspolitikken først og fremmest indeholdt disciplinerende foranstaltninger, idet arbejdsløse i stigende grad blev mødt med krav om aktivering og fik reduceret adgangen til dagpenge. Man kan hævde, at sikringen af den sociale tryghed først og fremmest skete gennem det markante fald $\mathrm{i}$ arbejdsløsheden, men vel også, at det i stigende grad blev utrygt at være arbejdsløs under denne periode. I øvrigt er det tvivlsomt om fleksibiliteten på arbejdsmarkedet overhovedet har været stigende (Lind 2004), til trods for at reguleringerne - især ændringerne i de kollektive overenskomster, jfr. nedenfor af arbejdsmarkedet rent faktisk har haft dette sigte.

\section{Aftalesystemet}

Selvom der er bred opbakning bag aftalemodellen, bliver overenskomstsystemet og specielt fagforeningernes interessevaretagelse af mange betragtet som en hæmsko for økonomisk vækst og en hindring for en optimal allokering af arbejdskraften - individuelle kontrakter og et friere marked for arbejdskraft vil bedre sikre konkurrenceevnen og reducere arbejdsløsheden. Men specielt i løbet af 1990'erne har aftaleindgåelserne på det danske arbejdsmarked ydet sit store bidrag til en forøget fleksibilitet på arbejdsmarkedet. Dette er først og fremmest sket gennem en radikal decentralisering af løndannelsen og arbejdstidens tilrettelæggelse. Normallønssystemet er blevet markant reduceret, og flere store overenskomstområder indeholder således nu ikke nogen lønsatser overhovedet.

Yderligere er den centrale lønfastsættelse i den offentlige sektor (og finanssektoren) blevet suppleret med et meget fleksibelt element - Ny løn - og både i den private og i den offentlige sektor finder betydende dele af løndannelsen nu sted på den enkelte arbejdsplads (de netop overståede overenskomstforhandlinger i 2005 har dog modificeret dette for visse grupper af offentligt ansatte). Den gennemsnitlige arbejdstid kan lokalt afviges med stadigt stigende udsving og over en stadigt længere periode, og på nogle områder kan der lokalt vælges mellem løn, ferie, uddannelse og pension. Som modydelse til denne fleksibilisering har lønmodtagerne fået udbygget pensionsordningerne og fået en gennemsnitlig lønstigning, der er på niveau med eller overstiger inflationen.

'Den frie overenskomstindgåelse' blev også i 1990'erne holdt i kort snor af regeringerne, som har grebet ind hver gang en overenskomstperiode er endt i konflikt, men til trods for gentagne perioder med et ret anstrengt forhold mellem regering og organisationer - specielt ændringen af efterlønsordningen i 1999 medførte en tydelig krise mellem regeringen og store dele af fagbevægelsen - er de korporative strukturer og relationer blevet styrket.

\section{Flere i Arbejde}

Den borgerlige regering blev i 2001 valgt ind på en forsikring om bevarelse af velfærdsstaten og havde således givet afkald på nogle af de markante liberalistiske temaer, der især havde præget partiet Venstre i løbet af 1990'erne. Fjendtligheden over for fagforeningerne var et af dem (f.eks. havde det igennem lang tid været Venstres hensigt at fjerne retten til at trække fagforeningskontingentet fra i skat), og den nye regering markerede da også tydeligt, at samarbejdet med organisationerne skulle fortsætte, ligesom statsministeren ved sin tiltræden proklamerede, at klassekampen var slut.

På det arbejdsmarkedspolitiske område var der også forsonlige toner. Politikken fra 1990'erne skulle fortsættes gennem nogle reformer, der skulle sikre vækst i beskæftigelsen og en bevarelse af den sociale sikker- 
hed. Alligevel viste det sig snart, at nogle af regeringens initiativer havde en klar liberalistisk profil - også i reguleringen af arbejdsmarkedet. Det gennemgående tema for regeringens politik var 'det frie valg', hvor borgeren skulle kunne vælge frit mellem offentlige og private serviceydelser, og $\mathrm{i}$ den såkaldte Frihedspakke var bl.a. intentioner om at etablere en statslig arbejdsløshedskasse uafhængig af fagforeningerne, en afskaffelse af begrænsninger $i$ at tage deltidsbeskæftigelse, samt et forbud mod eksklusivaftaler.

Forbudet mod eksklusivaftaler blev ikke gennemført, fordi Dansk Folkeparti blev betænkelige som følge af EU-udvidelsen, men det lykkedes regeringen at få kendt alle bestemmelser i overenskomster, der begrænsede adgangen til deltidsansættelse, for ulovlige. Den statslige arbejdsløshedskasse blev ikke vedtaget, idet Dansk Folkeparti heller ikke støttede dette. Derimod blev det i 2002 vedtaget, at arbejdsløshedskasser fremover kunne blive tværfaglige. Umiddelbart er denne øgede mulighed for 'frit valg' af arbejdsløshedskasse ikke nogen større forandring, men sammen med de følgende reformer bliver der hermed lagt op til nogle ret drastiske ændringer af reguleringen af arbejdsmarkedet.

Regeringen præsenterede i foråret 2002 sin arbejdsmarkedsreform Flere i Arbejde, og efter langvarige forhandlinger blev den vedtaget i december. Reformen indeholdt, som ovenfor nævnt, de sædvanlige sociale nedskæringer, specielt på kontanthjælpen, men også begrænsning i adgangen til dagpenge for personer under 30, hvilket var en direkte fortsættelse af den tidligere regerings politik. Dertil strengere sanktioner ved afslag af et arbejdstilbud, strengere rådighedskrav, samt en såkaldt forenkling af aktiveringsforanstaltningerne fra de eksisterende 32 ordninger til tre principielle redskaber. Videre blev det bestemt, at forsikrede og ikke-forsikrede ledige i princip- pet skulle behandles ens, og gennem etablering af samarbejdsinstitutioner skulle AF og kommunerne gå sammen om denne opgave. Endelig blev det fastlagt, at stigende dele af den samlede arbejdsmarkedspolitiske indsats skulle udliciteres til andre aktører (arbejdsløshedskasser, vikarbureauer, konsulentvirksomheder, uddannelsesinstitutioner eller andet). Med den efterfølgende strukturreform i 2004 er det som nævnt yderligere bestemt, at beskæftigelsespolitikken skal overgå til kommunerne.

Disse organisatoriske eller administrative reformer vil få vidtrækkende konsekvenser for reguleringen af arbejdsmarkedet i Danmark. Konsekvenserne for beskæftigelsespolitikken, herunder indflydelsen for arbejdsmarkedets parter, bliver analyseret $\mathrm{i}$ andre artikler i dette temanummer af Tidsskrift for Arbejdsliv. Det centrale spørgsmål er vel, om der i fremtiden vil være tale om at føre en egentlig arbejdsmarkedspolitik i stil med det, vi har kendt indtil nu, eller om det er et bevidst forsøg på at ødelægge de institutionelle rammer for en politisk, samfundsmæssig opbakning bag allokerings- og uddannelsesprocesser og i stedet lade individuelle markedsrelationer få mere frit spil.

Perspektiverne for kollektiv interessevaretagelse gennem fagforeninger peger $i$ hvert fald i en sådan retning. Nedbrydningen af de faglige grænser for medlemskab af arbejdsløshedskasser vil i hvert fald med stor sandsynlighed føre til faldende medlemskab af fagforeninger, specielt inden for LO-området, hvor organisationsgrænser og medlemskab af arbejdsløshedskasser igennem tiden nogenlunde har fulgt opdelingen af arbejdsmarkedet gennem kollektiv overenskomstindgåelse. Når arbejdsløshedskasserne fremover i stigende grad kan optage alle typer af medlemmer, nedbrydes den tætte forbindelse mellem arbejdsløshedskasse og fagforening, hvorved organisationsprocenten med al sandsynlighed vil 
falde fra de nuværende ca. 80\% til et niveau, der kendetegner lande uden en frivillig arbejdsløshedsforsikring. Dette vil selvsagt have alvorlige konsekvenser for fagforeningernes hele virke, hvorved den højt besungne 'danske model' vil gå trange tider i møde (Lind 2003).

Om regeringen rent faktisk har et sådant perspektiv i tankerne, ved vi selvsagt ikke noget om. Reformerne er ikke blevet begrundet med sådanne overvejelser, men derimod med hensigten om at fremme 'det frie valg'. Borgerne skal selv vælge - og hvis man frit kan vælge arbejdsløshedskasse, er der penge at tjene (Arbejdsdirektoratet 2004). Indtil videre er det formodentlig også kun et mindretal, der rent faktisk har skiftet arbejdsløshedskasse til de nye tværfaglige kasser, men mulighederne er der, og hvor længe kan LO-forbundene og de tilknyttede a-kasser fastholde en fælles strategi og undgå at konkurrere om medlemmerne?

\section{Socialpolitikken}

Selvom dele af socialpolitikken nu er blevet samlet med arbejdsmarkedspolitikken i Beskæftigelsesministeriet under betegnelsen beskæftigelsespolitik, viser det sig, at traditionerne i socialpolitikken ikke er grundlæggende forandret. Allerede med modernitetens første danske socialreform i 1891/ 92 blev kimen lagt til en dualisering af den velfærdsstat, som skulle udvikles i løbet af det næste århundrede. Godsejerne og gårdmændene fandt snart sammen om at trække alderdomsforsørgelsen og sygelovgivningen ud af Fattigloven hvorved de, som enten ikke før havde ligget det offentlige til byrde eller selv bidrog til egen sygdomssikring, nu var kvalificerede til den højere, finere og sanktionsfrie offentlig hjælp. De øvrige trængende var fortsat henvist til den lavere, stigmatiserende fattighjælp med tilhørende fattighjælpsvirkninger.

Da socialdemokratiet med K.K. Steincke i spidsen udformede og gennemførte modernitetens anden socialreform i 1933, var det stort set de samme liberalistiske principper, som denne reform byggede på. Med udbygningen af velfærdsstaten i det 20.århundrede blev flere og flere befolkningsklasser og -grupper tilgodeset gennem velfærdsstatslige ydelser. Uddannelsestøtte, familieydelser, boligtilskud herunder rentefradrag, folkepension og en lang række andre serviceog kontantydelser blev efter princippet om universalitet efterhånden ydet til alle landets borgere. Og i slutningen af århundredet blev mange sociale ydelser efterhånden betragtet som en borgerret - som den sociale del af medborgerskabet. Men alligevel var der stadigvæk to velfærdsstater: En for det store flertal af befolkningen, som arbejdsmæssigt og indkomstmæssigt klarede sig godt, og så en discount-udgave for det mindretal, som blev betragtet som mindreværdige borgere og derfor uværdigt trængende. Ser vi på den sidste kategori, er der selvfølgelig over tiden ikke i enhver henseende tale om den samme gruppe af personer og da slet ikke om identiske undergrupper. Disse ændrer sig - ikke så meget med socialpolitikken, der stadig udformes todelt - men snarere med ændringerne i de samfundsøkonomiske strukturer.

Så mens der er kontinuitet, for så vidt angår dualiseringen af velfærdsstaten, er der ændringer i sammensætningen og størrelsen af de grupper, som udgør de ikke-værdige dele af det sociale klientel. Steincke talte således om 'selvopgivende døgenigte' og 'samfundsfjendske elementer', mens fokus for Socialforskningsinstituttet som udtryk for regeringens og socialdemokratiets socialpolitiske tænketank under tilblivelsen af modernitetens tredje socialreform i 1960'ernes slutning/1970'ernes begyndelse var et andet sted. Instituttet gik således ud fra,

»at $i$ en periode med gode beskaeftigelsesforhold måtte langvarigt arbejdsløse adskille 
sig voesentligt fra befolkningens flertal.« (Friis \& Warburg 1960)

I dag er det især tilknytningen til arbejdsmarkedet, som er afgørende for dualiseringen af velfærdsstaten. Tilhører du det store flertal af personer i den arbejdsdygtige alder, som har en stabil eller nogenlunde stabil tilknytning til arbejdsmarkedet, så hører du sammen med børn og gamle til i den privilegerede del af velfærdsstaten. Og generelt gælder det, at jo længere tid af dit liv du arbejder, jo flere timer du arbejder, og jo højere løn du oppebærer, desto bedre er din placering i velfærdssystemet. Arbejdsmarkedspensionerne og arbejdsløshedsunderstøttelsen er gode eksempler. Men tilhører du de $20-25 \%$ af befolkningen, som i den erhvervsaktive alder ikke har foden solidt plantet inden for på arbejdsmarkedet, så er din understøttelse ved alderspension og arbejdsledighed væsentlig lavere. Siden begyndelse af 1950'erne er den sidste gruppe vokset fra at udgøre nogle ganske få procent til siden 1990'erne at være omkring hver fjerde/femte dansker i den erhvervsaktive alder (Møller 2004). Det er denne gruppe, som siden begyndelsen af 1980'erne har oplevet stadige reduktioner i både ydelsernes højde og i varigheden af ydelserne, kombineret med stigende krav til adgang til ydelserne i form af længere optjeningsperioder og ventetider.

Set i relation til reformen Flere i Arbejde er der på det socialpolitiske område tale om en kontinuitet i forhold til de forrige regeringer. Også de skar ned på de arbejdsmarginaliseredes og dermed uværdiges ydelser m.v. Over de seneste to årtier er der tale om dusinvis af forringelser (Lind \& Møller 2004). Og ligesom de forrige regeringer har den nuværende også fredet de velfærdsstatslige ydelser for det store flertal af befolkningen - dem med fast tilknytning til arbejdsmarkedet, børn og gamle.

Der, hvor der på det seneste er sket æn- dringer, er, at den nuværende regering gennem to runder af skattelettelser har privilegeret de $\mathrm{i}$ forvejen bedst stillede grupper $\mathrm{i}$ samfundet, og at disses forbedrede levekår nu bindes direkte sammen med forringelserne for de marginaliseredes. Det hedder således i forliget Flere $i$ Arbejde, at

»Flere i Arbejde generelt vil medføre foerre forsørgelsesudgifter alene som følge af regelaendringer (kontanthjoelpsloft mv.) Disse besparelser reserveres til nedsoettelse af skatten fra 1. Januar 2004." (Socialrådgiveren 2004)

Dualiseringen af velfærdsstaten hviler altså ikke længere så tydeligt alene på tilknytningen til arbejdsmarkedet. Nu er det også indkomsten - også den del, der ikke erhverves ved arbejde - som via mærkbare skattelettelser er med til at skærpe den velfærdsstatslige todeling. Fogh-regeringen har klart markeret et nyt niveau for levestandard gennem den lave starthjælp, samt yderligere sænkning af kontanthjælpen. Argumentet har været, at det skal motivere kontanthjælpsmodtagerne til at blive selvforsørgende, og jo større forskel der er mellem lønindkomst og overførselsindkomst, des større er incitamentet. Imidlertid er en stor del af kontanthjælpsmodtagerne syge, nedslidte eller har andre sociale problemer, som forhindrer dem i at opnå et indtægtsgivende arbejde.

Endelig er der i en dualiseringssammenhæng grund til i de allerseneste år at hæfte sig ved den yderligere skærpelse, der er sket via regeringsstøtte til/accept af boligejernes muligheder for yderst fordelagtige lånoptagelser i boligernes friværdi. Gennem lave renter og afdragsfri perioder for boliglån har mange boligejere opnået markante forbrugsudvidelser.

Sammenfattende er der således sket en skærpelse af den velfærdsstatslige dualisering og dermed en yderligere polarisering af 
levevilkårene mellem de, der har en mere eller mindre solid forankring på arbejdsmarkedet, børn og gamle på den ene side og den marginaliserede rest på anden.

\section{Afslutning}

Man kan ikke bebrejde statsministeren, at han påstår, at klassekampen er slut - han gentager blot det, som alle andre borgerlige ideologer altid har hævdet. Det er bare en smule overraskende, at regeringen umiddelbart efter sin tiltrædelse fører en politik, der forringer levevilkårene for de grupper af befolkningen, der i forvejen er værst stillede med hensyn til beskæftigelse og indkomst. I særdeleshed modtagerne af sociale overførselsindkomster. I tilgift har regeringen rettet markante angreb mod lønmodtagernes organisationer og arbejdsmarkedets aftalesystem, herunder a-kasselovgivningen og parternes indflydelse på administrationen af beskæftigelsespolitikken.

De eksplicitte begrundelser herfor er at forøge borgernes mulighed for at foretage et 'frit valg' og øge incitamentet til at tage et arbejde. Men det er kun den ene side af sagen, som bruges til at markedsføre den borgerlige politik som et frigørende projekt. Det reelle indhold er, at der gennem nedskæringer i ydelserne, stramninger i adgangen til og varigheden af ydelserne og en styrkelse af aktiveringsindsatsens motiverende effekter sker en yderligere disciplinering, ikke bare af de arbejdsløse, men også af det store flertal af arbejdende lønmodtagere. For dem bliver det stadigt mere skræmmende og socialt udstødende at blive arbejdsløs, og det lægger naturligt en dæmper på deres krav til arbejdets kvalitet, samt løn og øvrige arbejdsbetingelser, hvilket bl.a. har kunnet ses i det forløbne år (2004) med en svagere lønstigning i forhold til foregående år og med accepten af lønnedgang blandt billetsælgerne i SAS i begyndelsen af året og slagteriarbejderne på Danish Crown i Ringsted i december måned.

Det kan således godt være, at statsministeren mener, at klassekampen er slut, men man kan altså lige så godt sige det modsatte, nemlig at regeringens førte politik tyder på, at klassekampen lever i bedste velgående.

Uligheden mellem beskæftigede og forsørgede er forøget - også gennem skattepolitikken og accepten af, at personer med fast ejendom i disse år også er blevet begunstiget med nye forbrugsmuligheder som følge af den faldende rente og - på det seneste - afdragsfrie lån.

Sat på kort formel er det hovedsageligt indpakningen, der adskiller sig fra tidligere regeringers arbejdsløshedspolitik. Med undtagelse af de store strukturelle og organisatoriske reformer af arbejdsløshedspolitikken - specielt a-kasselovgivningen - og de øvrige slet skjulte angreb på fagbevægelsen kunne tidligere socialdemokratiske regeringer have ført den samme politik. Tendensen har været nøjagtigt den samme siden 1979, hvor de første begrænsninger i adgangen til arbejdsløshedsdagpenge blev gennemført efter de store reformer i socialog arbejdsmarkedspolitikken i 1960'erne og 1970'erne.

Flere i Arbejde er altså på nogle punkter en fortsættelse af nogle almene tendenser i tilpasningen af velfærdsstaten til et neo-liberalistisk regime. Kontinuiteten ligger således i, at de selektive politikker får tillagt større betydning i beskæftigelsespolitikken, når finanspolitikkens muligheder begrænses. Beskæftigelsespolitikken skal stadigvæk fremme en effektiv allokering af arbejdskraften, forbedre eller vedligeholde dens kvalitet og sørge for, at der er en tilstrækkelig - og gerne overskydende - mængde, så lønstigninger ikke medfører for høj inflation. Et vigtigt led i disse bestræbelser er selvsagt at sikre, at arbejdsløshed ikke er attraktivt. Der skulle gerne være effektive in- 
citamenter og motivationsfaktorer til at søge arbejde.

På andre punkter, de strukturelle og organisatoriske forandringer, er reformen tilsyneladende ret uskyldige tiltag, der skal sikre borgerne et 'frit valg'. Men den indeholder kimen til en total omstrukturering af beskæftigelsespolitikken og en svækkelse af lønmodtagernes organisering i fagforeninger, hvilket selvsagt vil ændre relationerne på arbejdsmarkedet ret radikalt. Her viser regeringens klassepolitik sig i allerhøjeste grad. Det er et klassisk liberalistisk dogme, at fagforeningerne ødelægger den frie konkurrence på markedet, hvorved lønnen presses i vejret med arbejdsløshed og mindsket økonomisk vækst til følge. Stækkes fagforeningernes magt og indflydelse, vil der også blive lettere adgang til at sikre høje profitter.

Kommunernes overtagelse af arbejdsmarkedspolitikken og den tiltagende introduktion af private aktører bliver fremstillet som velegnede redskaber til en effektiv - og altså billigere og bedre - forvaltning af beskæftigelsespolitikken. Tror regeringen selv på dette, og i givet fald: Er denne tro baseret på andet end ideologiske dogmer? Og tror regeringen selv på, at disse reformer vil medføre flere i arbejde? Vi tillader os at tvivle.

Flere i Arbejde er også en videreførelse af den dualiserede velfærdsstat. Selvom ligebehandlingen af forsikrede og ikke-forsikrede ser ud til at mindske forskellen i serviceydelser mellem disse to grupper, består der dog grundlæggende forskelle mellem dem, men det er sandsynligvis korrekt, at de nu begge stort set vil blive præsenteret for samme krav til aktivering mv. Alt efter temperament kan man måske hævde, at de markante forringelser af kontanthjælpen for specielle grupper kunne medføre, at velfærdsstaten nu er blevet 'tredelt', hvor de svageste nu får så lave ydelser, at man har svært ved at forstå, hvordan de kan eksistere rent materielt uden at bryde loven. Den svageste gruppe er nu blevet indvandrergruppen, som efterhånden behandles som en ren under-klasse.

Der er ikke kommet flere i arbejde som følge af Flere i Arbejde. Det kan man ikke udelukkende bebrejde regeringen. Ret beset er der vel ikke ret meget af indholdet i denne pakke, der er beregnet til - endsige velegnet til - at bringe flere i arbejde. Hovedindholdet er en opstramning af den lovgivning, der regulerer forholdene for de arbejdsløse - og det skaber kun flere i arbejde i den forstand, at der er en omfattende beskæftigelse i at kontrollere, administrere, aktivere og uddanne arbejdsløse. At tro på, at forringelser af de arbejdsløses levevilkår skulle medføre flere jobs er i bedste fald naivt. At blive ved med at hævde det er uanstændigt.

Regeringen havde troet, at skattelettelserne medførte højere beskæftigelse. Det har sikkert også været tilfældet, men den yderligere efterspørgsel har åbenbart ikke kunnet kompensere for andre faktorer, der har medført et fald i efterspørgslen på arbejdskraft. 


\section{REFERENCER}

Arbejdsdirektoratet (2004): Benchmarking af arbejdsløshedskasserne 2004, København, Arbejdsdirektoratet.

Auer, P. (2000): Employment revival in Europe, Geneva, ILO.

Beskæftigelsesministeriet: DREAM-databasen.

Beskæftigelsesministeriet (2002): Handlingsplan for Flere i arbejde, København, Beskæftigelsesministeriet.

CASA \& Socialpolitisk Forening (2003): Social Årsrapport 2004, København.

CASA \& Socialpolitisk Forening (2004): Social Årsrapport 2004, København.

Danmarks Statistik: Statistikbanken.

DØR (2004): Dansk Økonomi efterår 2004, København, Det Økonomiske Råd.

Finansministeriet (2004): Økonomisk Redegørelse, København, Finansministeriet, december.

Friis, H. \& E. Warburg (1960): Offentligt forsorgsunderstøttede, Socialforskningsinstituttets Publikationer no 1, København, Teknisk Forlag.

Ganssmann, H. (2000): Labour market flexibility, social protection and unemployment, i European Societies, 2, 3, 243-269.

Hansen, F. K. \& H. Hansen (2004): Starthjoelp og introduktionsydelse - hvordan virker ydelserne?, København, CASA.

Lind, J. (1995): Unemployment policy and social Integration, i N. Mortensen (ed.): Social Integration and Marginalisation, København, Samfundslitteratur, 183-205.

Lind, J, \& I. H. Møller (2004): The Danish experience of labour market policy and activation of the unemployed, i Serrano, A.: Are Activation Policies Converging in Europe, Brussels, ETUI, 163-196.
Lind, J. (2004): Labour Market Policy in Denmark - A European success Story?, i J. Lind, H. Knudsen \& H. Jørgensen (eds.): Labour and Employment Regulation in Europe, Brussels, P.I.E. Lang, 299-322.

Lind, J. (2003): Arbejdsmarkedsreformen og vejen til det frie valg på arbejdsmarkedet, i Tidsskrift for Arbejdsliv, 5, 2, 73-77.

Møller, I. H. (2004): De fire socialreformer i moderne tid, i J. E. Larsen \& I. H. Møller: Socialpolitik, København, Hans Reitzels Forlag.

Politiken (2004): 13. og 14. juli.

Regeringen (1987): Foelleserkloering fra Regeringen, DA, LO, FTF \& SALA, 8. december. Socialrådgiveren (2004): De udsatte - På varig fattigdom, redaktionel artikel. 19, 3 .

Transfer (2004): Flexicurity - Conceptual issues and political implementation in Europe, 10, 2.

Jens Lind, ph.d, lektor ved Aalborg Universitet.

e-mail: jlind@socsci.aau.dk

Iver Hornemann Møller, cand.polit., dr. merc., professor i socialt arbejde ved Væxjø Universitet (Sverige) samt i sociologi ved Universitetet i Coimbra (Portugal).

e-mail:ihm.cid@cbs.dk

Henning Hansen, cand.polit., konsulent ved Center for Alternativ Samfundsanalyse (CASA).

e-mail: heh@casa-analyse.dk 